\title{
ANALISIS KEMUNGKINAN TERJADINYA KONDENSASI PADA PIPA ALIR UAP DARI SEPARATOR KE SCRUBBER BERDASARKAN MODEL PENURUNAN TEKANAN PADA PLTP AREA LAHENDONG UNIT $5 \& 6$
}

\author{
Brenda Bella Gunena, Djeli Alvi Tulandi, Jeferson Polii \\ Fakultas Matematika dan Ilmu Pengetahuan Alam, Universitas Negeri Manado \\ email: bb99gunena@gmail.com
}

\begin{abstract}
ABSTRAK
Produksi panas bumi pada turbin uap, harus memperhatikan kualitas uap yang masuk karena jika ada steam yang terkondensasi maka akan berpengaruh pada efektivitas kerja turbin, sehingga tujuan dari penelitian ini yaitu mengkaji kemungkinan terjadinya kondensasi pada pipa alir uap. Metode yang dipakai dalam penelitian ini yaitu deskriptif analitis, dimana setiap parameter pengukuran dihitung menggunakan Microsoft Office Excel dengan pemograman steam prog serta menggunakan persamaan Harrison and Friston yang perhitungannya per segmen panjang pipa $(3 \mathrm{~m})$ serta dilakukan perhitungan fraksi uap (x) dan panjang pipa dalam sebuah grafik yang menjadi penentuan hasil akhir dari penelitian ini. Hasil grafik antar fraksi uap dan panjang pipa menyatakan bahwa nilai fraksi uap sepanjang pipa uap terus meningkat sampai 0,9997 (99.98\%) hampir menjadi 1 (100\%) artinya tidak terjadi kondensasi di dalam pipa uap dari separator ke scrubber.
\end{abstract}

Kata kunci: Penurunan tekanan, Kualitas uap, Kondensasi

\begin{abstract}
Geothermal production in steam turbines must pay attention to the quality of the incoming steam because if their steam is condensed it will affect the effectiveness of the turbine, so the purpose of this study is to examine the possibility of condensation in the pipe steam flow. The method used in this research is descriptive, where each parameter measurement is calculated using Microsoft Office Excel programming steam prog and using the Harrison and Friston equation which calculates per segment of pipe length $(3 \mathrm{~m})$ and calculates the vapor fraction $(x)$ and pipe length in a graph which determines the final result of this study. The graph results between the vapor fraction and the length of the pipe show that the vapor fraction value along the steam pipe continues to increase until 0.9997 (99.98\%) almost becomes 1 (100\%) meaning that there is no condensation in the steam pipe from the separator to the scrubber.
\end{abstract}

Keywords: Pressure drop, Steam quality, Condensation 


\section{PENDAHULUAN}

Sistem panas bumi dibagi dalam tiga bagian yaitu sistem bersuhu rendah memiliki temperatur reservoar $<125^{\circ} \mathrm{C}$, sistem bersuhu sedang memiliki temperatur reservoar antara $125-225^{\circ} \mathrm{C}$ dan sistem bersuhu tinggi memiliki temperatur reservoar $>225^{\circ} \mathrm{C}$ (Hochstein dalam Yuliansyah, 2016). Dilihat dari pembagian sistem panas bumi, Indonesia merupakan sistem panas bumi hydrothermal yang memiliki temperatur tinggi $\left(>225^{\circ} \mathrm{C}\right)$ dan berdasarakan jenis fluida produksi dan jenis kandungan fluida maka system hydrothermal dibedakan menjadi dua yaitu sistem satu fasa dengan dominasi air saja (brine) atau uap saja (steam) dan sistem dua fasa dengan dominasi uap air dan air (steam dan brine).

Untuk dapat memanfaatkan energi panas bumi dibutuhkan lokasi yang memiliki system geothermal. System geothermal terdiri dari tiga elemen utama: (1) batuan reservoir yang permeable, (2) air yang membawa panas dari reservoir ke permukaan bumi dan (3) sumber panas. Selain itu, hal esensial yang dibutuhkan untuk keberadaan system geothermal adalah (1) sumber panas yang besar, (2) reservoir untuk akumulasi panas, (3) batuan penudung (cap rock) untuk menjaga akumulasi panas (Firdaus, A., dkk. 2014). Keseluruhan komponen tersebut harus dalam satu kesatuan sistem agar sistem panas bumi ini dapat dimanfaatkan secara efektif (Agustomo, 2013).

Pemanfaatan panas bumi sebagai sumber listrik diketahui masih kurang karena produksi panas bumi memiliki biaya yang mahal dan pemanfaatannya hanya dapat dilakukan pada lokasi yang memiliki komponen-komponen sistem panas bumi dan hanya dapat dimanfaatkan untuk daerah tersebut. Sulawesi Utara merupakan salah satu yang telah mengembangkan pemanfaatan energi panas bumi tersebut lebih khusus pada daerah Lahendong dimana pada daerah ini telah di operasikan Pembangkit Listrik Tenaga Panas Bumi (PLTP) Lahendong Unit 5 \& 6 dengan jenis fluida produksi yaitu sistem dua fasa dan telah memiliki kapasitas 20 megawatt.

Pada PLTP Lahendong turbin yang dipakai adalah turbin uap maka fluida produksi dengan sistem dua fasa akan dipisahkan pada separator. Setelah terjadi pemisahan pada separator, uap atau steam yang telah dipisahkan dari brine akan digunakan untuk memutar turbin. Namun pada saat steam menuju ke turbin, biasanya akan terjadi penurunan tekanan yang mengakibatkan terjadinya kondensasi di dalam pipa. Akibat dari kondensasi yang terjadi pada pipa alir steam, turbin menjadi rusak karena turbin uap hanya mampu menerima $1 \%$ kadar air saja. maka ketika terjadi kondensasi kadar air dalam pipa steam akan menjadi lebih banyak untuk itu diantara separator dan turbin di buat scrubber untuk meningkatkan kadar uap air sehingga kerja turbin menjadi efektif.

\section{METODE PENELITIAN}

Saptadji (2001) menyatakan bahwa persamaan dasar untuk penurunan tekanan adalah

$\left(\frac{d p}{d z}\right)_{\text {total }}=\left(\frac{d p}{d z}\right)_{\mathrm{f}}+\left(\frac{d p}{d z}\right)_{\mathrm{g}}+\left(\frac{d p}{d z}\right)_{\mathrm{acc}}$

Dimana :

$\left(\frac{d p}{d z}\right)_{\mathrm{f}}=$ kehilangan tekanan karena gesekan

$$
=5-10 \% \text { dari }\left(\frac{d p}{d z}\right)_{\text {total }}
$$

$\left(\frac{d p}{d z}\right)_{\mathrm{g}}=$ kehilangan tekanan karena elevasi

$$
=80-95 \% \text { dari }\left(\frac{d p}{d z}\right)_{\text {total }}
$$

$\left(\frac{d p}{d z}\right)_{\text {acc }}=$ kehilangan tekanan karena akselerasi (kecil, sehingga sering diabaikan)

Harisson dan Freeston menentukan penurunan tekanan karena gesekan dan akselerasi berdasarkan persamaan berikut :

Dimana :

$$
\left(\frac{d p}{d z}\right)_{\mathrm{f \& acc}}=\frac{4 \tau_{\omega}}{D(1-A C)}
$$

$\tau_{\omega}=\frac{\lambda V_{f}^{2}}{8 u_{f}}$

$V_{f}=\frac{m(1-a) v_{f}}{(1-a) A}$

$\mathrm{A}=\frac{\pi D^{2}}{4}$

Dengan $\tau_{\omega}$ adalah shear stress, $\lambda$ adalah faktor friksi, $\bar{V}_{f}$ adalah kecepatan fasa fluida, $\mathrm{m}$ adalah laju alir steam, AC adalah acceleration correction, A adalah luas penampang pipa dan $u_{f}$ adalah volume spesifik fasa gas.

Faktor friksi $\lambda$ ditentukan dengan metode yang dikembangkan Churchill tahun 1977 yang mengembangkan persamaan korelasi tunggal yang menghubungkan faktor friksi dengan bilangan Reynold dan kekasaran pipa untuk aliran laminar, transisi, turbulen. Faktor friksi dapat diperoleh dengan persamaan berikut (Freeston, 1996).

$$
\lambda=8\left[\left(\frac{8}{R e}\right)^{12}+\frac{1}{(A+B)^{3 / 2}}\right]^{1 / 12}
$$


Dengan :

$$
\begin{aligned}
& \mathrm{A}=\left[2,457 \operatorname{In} \frac{1}{\left(\frac{7}{R e}\right)^{0,9}+0,27\left(\frac{\varepsilon}{D}\right)}\right]^{16} \\
& \mathrm{~B}=\left[\frac{37530}{R e}\right]^{16}
\end{aligned}
$$

Dimana $\mathrm{D}$ adalah diameter dalam pipa, $\varepsilon$ adalah kekasaran pipa dan $\mathrm{Re}$ adalah bilangan Reynold.

Untuk aliran dalam pipa bilangan Reynold dapat diperoleh dari persamaan sebagai berikut.

$$
\operatorname{Re}=\frac{\rho V_{f} D}{\mu}
$$

Dimana $\rho$ adalah densitas fluida, $V_{f}$ adalah kecepatan fluida dan $\mathrm{D}$ adalah diameter pipa. $\alpha$ adalah void friction uap yang diperoleh dari persamaan :

$$
\alpha=\frac{1}{1+\left(\frac{1-x}{x}\right)^{0.8}\left(\frac{v_{f}}{u_{g}}\right)^{0.515}}
$$

Dimana $\mathrm{x}$ adalah fraksi uap dan $\mathrm{u}_{\mathrm{g}}$ adalah volume spesifik fasa uap.

Perhitungan penurunan tekanan aliran fluida dua fasa memiliki AC yang ditunjukan dengan persamaan :

$$
\mathrm{AC}=\frac{m^{2} x^{2} v_{g}}{P A^{2} \alpha}
$$

Dimana $\mathrm{P}$ adalah tekanan fluida.

Persamaan utuk penurunan tekanan karena elevasi :

$$
\left(\frac{d p}{d z}\right)_{g}=\rho g \sin \theta
$$

Dimana g adalah percepatan gravitasi dan $\rho$ adalah densitas fluida yang diperoleh dari persamaan berikut.

$$
\rho=\alpha \rho_{g}+(1-\alpha) \rho_{f}
$$

Dimana $\rho_{f}$ adalah densitas fasa cair dan $\rho_{g}$ adalah densitas fasa uap.

Besarnya kehilangan tekanan dalam pipa, dapat diperoleh dari persamaan

$$
\text { Kehilangan tekanan }=\left(\frac{d p}{d z}\right)_{\text {total }} \mathrm{x} \text { panjang }
$$
pipa.

\section{HASIL DAN PEMBAHASAN}

Perhitungan Penurunan Tekanan Pada Pipa Alir Uap dari Separator ke Scrubber

Perhitungan penurunan tekanan dilakukan pada pipa alir uap dari separator sampai scrubber.

Polii (2017) meyatakan bahwa perhitungan penurunan tekanan pada masingmasing sekmen akan membantu pencegahan penurunan temperatur saturasi dan pengendapan silika. Sehingga dalam pnelitian ini dilakukan perhitungan per segmen pipa, dimana segmen pipa dibagi rata-rata tiga meter berdasarkan elevasinya.

Perhitungan dilakukan dengan menggunakan Microsoft Excel menggunakan data pipa dari separator ke scrubber dengan kekasaran pipa Carbon Steel menggunakan data Pipe Absolute Roughness Value sebesar 5 $\mathrm{x} 10^{-5} \mathrm{~m}$. Pipa Carbon Steel 24 inch dengan schedule 80 memiliki diameter dalam 0.5668 $\mathrm{m}$. Hasil perhitungan penurunan tekanan uap di dalam pipa ditunjukan pada grafik berikut.

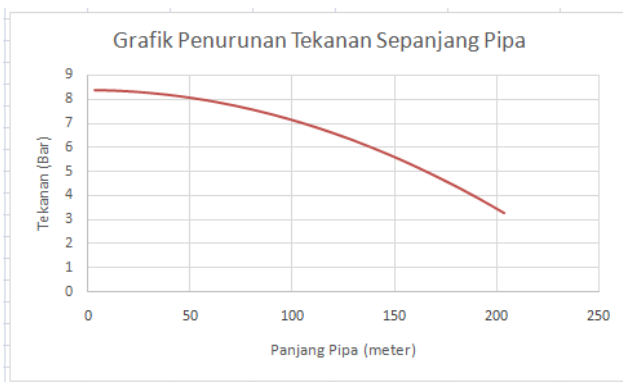

Gambar 1. Penurunan tekanan fluida steam sepanjang pipa separator ke scrubber

Fuida steam di lapangan panas bumi Lahendong yang mengalir melewati pipa separator ke scrubber mengalami penurunan tekanan yang berdampak pada penurunan temperature saturasi dimana selain kehilangan panas secara alami, steam juga akan kehilangan energi dalam bentuk panas. Hal ini karena adanya perpindahan panas secara radiasi dari pipa ke lingkungan. Panas yang hilang tersebut di dapatkan dari hilangnya entalpi sehingga steam akan berubah fasa menjadi cair atau kondensasi.

\section{Perhitungan Penurunan Tekanan Pada Pipa} Alir Uap dari Separator ke Scrubber

Untuk mengetahui adanya pembentukan kondensasi pada pipa sepanjang separator ke scrubber maka dibuat grafik perhitungan $\mathrm{x}$ (panjang pipa) dan y (fraksi uap) seperti pada gambar 2.

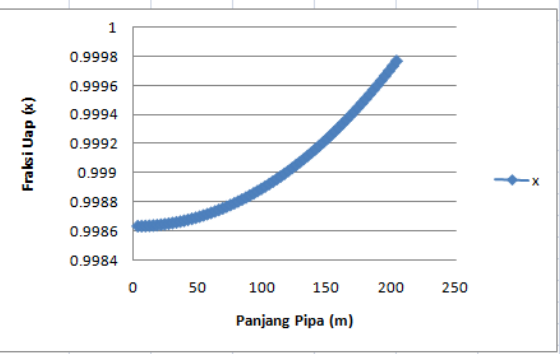

Gambar 2. Grafik Untuk Menentukan Terjadinya Kondensasi 
Dari grafik pada gambar 2, pada sepanjang jalur pipa dari separator ke scrubber tidak terjadi kondensasi karena nilai fraksi uap sepanjang panjang pipa terus meningkat sampai 0.999771 (99.98\%) artinya hampir menjadi 1 $(100 \%)$ uap. Hal ini berarti kualitas uap sepanjang pipa dari separator ke scrubber tidak mengalami penurunan kualitas uap (sebaliknya kualitas uap semakin naik), sehingga tidak diperlukannya condensate traps (perangkap air kondensasi) di sepanjang pipa alir uap dari separator ke scrubber.

\section{KESIMPULAN}

Berdasarkan persamaan Harisson dan Freeston hingga dibuat grafik penurunan tekanan dengan $\mathrm{x}$ (panjang pipa) dan $\mathrm{y}$ (tekanan) maka dapat dilihat bahwa uap mengalami penurunan tekanan karena adanya perpindahan panas secara radiasi dari pipa ke lingkungan. Panas yang hilang tersebut didapatkan dari hilangnya entalpi sehingga steam akan berubah fasa menjadi cair atau terkondensasi.

Grafik kualitas uap sepanjang pipa dari separator ke scrubber terus meningkat sampai $0.999771(99.98 \%)$ artinya hampir menjadi 1 (100\%) uap artinya tidak terjadi kondensasi di dalam pipa uap.

\section{REFERENSI}

Agustomo, I. (2013). Identifikasi Sistem Panas Bumi Dengan Menggunakan Metode AMT da MT di Daerah Simisuh, Pasaman, Sumatra Barat. Depok: Universitas Indonesia.

Firdaus, A., Harmoko, U., \& Widada, S. (2014). Pemodelan Steady State Sistem Panas Bumi Daerah Sumber Air Panas DiwakDerakan Dengan Menggunakan Software Hydrothrem 2.2. Yongster Physic Journal Vol. 3, No. 4, 243-250.

Polii, J. (2017). Pemodelan Penurunan Tekanan Brine di Dalam Pipa Injeksi pada Lapangan Panas Bumi Dieng. Jurnal MIPA UNSRAT Online , 32-35.

Saptadji, N. M. (2001). Teknik Panas Bumi. Bandung: Institut Teknologi Bandung.

Yuliansyah. (2016). Identifikasi Zona Reservoar Lapangan Panas Bumi Guci Jawa dan Metode Magnetotelurik. Lampung: Universitas Lampung. 